Creative commons User License: CC BY-NC-ND

Abstracted by: EBSCOhost, Electronic Journals Service (EJS),

Google Scholar, Directory of Open Access Journals (DOAJ),

Journal Seek, Scientific Commons,

Food and Agricultural Organization (FAO), CABI and Scopus
Journal of Agricultural Extension

Vol. 21 (3) October, 2017

ISSN(e): 24086851; ISSN(Print); 1119944X

http://journal.aesonnigeria.org

http://www.ajol.info/index.php/jae

Email: editorinchief@aesonnigeria.org

\title{
Niche Marketing Potentials for Farm Entrepreneurs in Nigeria
}

https://dx.doi.org/10.4314/jae.v21i3.13

\author{
Anzaku, T.A.K \\ Department of Agricultural Extension and Management, \\ College of Agriculture P.M.B.33 Lafia, Nigeria \\ Corresponding author Email: anzakutim@yahoo.com; Phone number: +2348032107554
}

\section{Salau, E.S}

Department of Agricultural Economics and Extension, Faculty of Agriculture, Nasarawa State, University, Keffi, Nigeria.

\begin{abstract}
Niche marketing can be a form of diversification and a means to achieving business success in all economic climates-boom, recession and depression. There are several niche marketing potentials farm entrepreneurs can exploit in start-up and existing small and large farm businesses. Dynamic entrepreneurism, and marketing tools and a are important in creating niche market opportunities which can be nurtured to yield the expected success by employing marketing and other appropriate corporate management strategies. In Nigeria, vast niche marketing potential that exists in general farm business, domestic and export markets, processing, product differentiation, organics, and other value addition sought by consumers can be tapped. For the vast majority of the farmers who are not operating farming as a business, intensive step-by-step training in farm business and then entrepreneurship is required for them to understand and imbibe niche marketing. People already in farm business can be further trained in niche aspects of entrepreneurship to enable them create niche markets. The knowledge of the trainers should be continually upgraded to equip them to do so. Government should therefore facilitate the training of extension workers, farmers and business people in this specialized aspect of marketing for the overall good of the participants and the economy.
\end{abstract}

Keywords: Niche, Marketing, Entrepreneurship, Potential, Business.

\section{Introduction}

Niche marketing is open to start-up, established, small and large scale businesses. Successful niche marketing operators make high gain margins for the unique product(s) they create and face less threat of competition (Kotler, 2003). The success is often the reward of entrepreneurism in the ever changing political, economic, socio-cultural and legal business environments, on one hand, experience, knowledge and skills acquired over time in business ventures, on the other. The role niche marketing plays in the development of agricultural marketing systems can be significant if more farm entrepreneurs understand, embrace and operationalize it. 
Creative commons User License: CC BY-NC-ND

Abstracted by: EBSCOhost, Electronic Journals Service (EJS),

Google Scholar, Directory of Open Access Journals (DOAJ),

Journal Seek, Scientific Commons,

Food and Agricultural Organization (FAO), CABI and Scopus
Journal of Agricultural Extension

Vol. 21 (3) October, 2017

ISSN(e): 24086851; ISSN(Print); 1119944X

http://journal.aesonnigeria.org

http://www.ajol.info/index.php/jae

Email: editorinchief@aesonnigeria.org

\section{Objectives of the Study}

The specific objective of the paper was to provide information on the basic requirements of niche marketing needed by prospective investors and extension educators.

\section{Methodology}

It is a synthesis of research and other relevant information gleaned from different sources cited in the various portions of the text.

\section{Niche Marketing}

Niche marketing involves targetting a product or service to a small but specific well defined segment of the population or market (extension.psu.edu). A niche segment of a market could be a geographical area, specialty industry, ethnic or religious group, or a particular age group (www.agmrc.org). Common niche product range of farm origin includes local products, organics, humanely treated livestock sought by specific consumer segments (Thilmany, http://valueaddedag.org). A variation of a common product that is not produced and marketed by the main marketing firms could be a niche product (http://agecoext.tamu.edu). A niche market is therefore a subset (segment) of the market within the larger marketplace consisting of group of consumers who seek distinctive mix of benefits, and have similar demographic, buying behaviour and/or lifestyle characteristics (Kotler, 2003; Thilmany, http://valueaddedag,org) .

\section{Potentials for Niche Marketing in Nigeria}

Niche markets are inexhaustible. They continue to evolve as consumers' tastes and interests of employees and family members continue to change. Table 1 is a snapshot of the general scenario of the existence of broad and niche marketing opportunities which prospective farm entrepreneurs can exploit in Nigeria for global and domestic markets. The essence of the potentials for niche markets presented in Table 1 is to show that products of the mainstream providers (examples of product marketed) could be narrow niche market providers in some places or there could be unique portion of this market to be served. Detailed research can reveal many more cases in each category. Domestic and/or international consumers are becoming increasingly interested in differentiated, customized, primary processed, organic and certified (e.g export, organic, fair trade, halal, rainforest alliance) niche products. Products are differentiated by branding, product and service quality, after sales support and appearance. Customized products are developed to the specifications of individual consumers. Examples of primary processed products include meat, milled rice, gari, cassava pellets, dehusked egusi, dried (smoked) fish. Organic foods are usually perceived as being safer (pesticide- free) and having a higher nutritional value or benefit. Agritourism is a growing segment of holiday seekers who prefer farm environment resorts. There can be global and domestic niche markets for the Chinese who seek to have pork as a delicacy, Asians who prefer beef with extra fat (extension.psu.edu) and Nigerians whose favourite delicacy is dog meat. These are examples of consumers of products of special demographic interest. 
Creative commons User License: CC BY-NC-ND

Abstracted by: EBSCOhost, Electronic Journals Service (EJS), Google Scholar, Directory of Open Access Journals (DOAJ), Journal Seek, Scientific Commons,

Food and Agricultural Organization (FAO), CABI and Scopus
Journal of Agricultural Extension

Vol. 21 (3) October, 2017

ISSN(e): 24086851; ISSN(Print); $1119944 X$

http://journal.aesonnigeria.org

http://www.ajol.info/index.php/jae

Email: editorinchief@aesonnigeria.org

\section{Requirements for Creating Niche Market Opportunity}

It is not sufficient to intuitively know of the existence of niche marketing opportunity but to also successfully exploit it. To do so, dynamic entrepreneurism, systematic identification of needs, and wants of consumers, and the capability, core competency and competitive advantage of existing firms are requirements at one time or the other.

\section{Table 1: Examples of possible niche markets for entrepreneurs in Nigeria}

\begin{tabular}{|c|c|c|c|}
\hline Farm Business subsector & Example of products marketed & Potential niche product(s) & $\begin{array}{l}\text { Targeted consumer of niche } \\
\text { products }\end{array}$ \\
\hline Inputs supply and distribution & $\begin{array}{l}\text { Seeds, agrochemicals, } \\
\text { livestock feeds, farm } \\
\text { machinery and equipment }\end{array}$ & $\begin{array}{l}\text { Consultancy services, after sales } \\
\text { services. Pest control products of plant } \\
\text { origin }\end{array}$ & Producers, government \\
\hline Product distribution & $\begin{array}{l}\text { Grains, vegetables, fruits, } \\
\text { tubers, oil seeds, live } \\
\text { livestock, meat, fish products }\end{array}$ & $\begin{array}{l}\text { Customized products, organics, certified } \\
\text { (organic, halal and/or fair trade), } \\
\text { differentiated products, primary } \\
\text { processed products }\end{array}$ & $\begin{array}{l}\text { Consumers/consumer groups } \\
\text { who are interested in the } \\
\text { specific products or product } \\
\text { range }\end{array}$ \\
\hline Arable farming & $\begin{array}{l}\text { Rice, yam, cassava, cowpea, } \\
\text { maize, spinach, cabbage, } \\
\text { lettuce, wheat, soyabean }\end{array}$ & $\begin{array}{l}\text { Customized products, organics, certified } \\
\text { products, differentiated products, } \\
\text { primary processed products, products of } \\
\text { special demographic interest, products } \\
\text { of agroforestry (fodder, timber, fuel, } \\
\text { food, medicine), agritourism }\end{array}$ & $\begin{array}{l}\text { Consumers/consumer groups } \\
\text { who are interested in the } \\
\text { specific products or product } \\
\text { range }\end{array}$ \\
\hline Tree crop farming & $\begin{array}{l}\text { Oil palm, cocoa, rubber, citrus, } \\
\text { mango, cashew, banana, } \\
\text { apple, pear }\end{array}$ & $\begin{array}{l}\text { Fruit juice, honey, wine flowers, } \\
\text { organics, certified products, agritourism, } \\
\text { customized products }\end{array}$ & $\begin{array}{l}\text { Consumers/consumer groups } \\
\text { who are interested in the } \\
\text { specific products or product } \\
\text { range }\end{array}$ \\
\hline Livestock production & $\begin{array}{l}\text { Cattle, sheep, goats, poultry, } \\
\text { rabbits }\end{array}$ & $\begin{array}{l}\text { Kosher milk, goat milk, meat, snails, } \\
\text { grass cutter, feed distribution, } \\
\text { customized products }\end{array}$ & $\begin{array}{l}\text { Consumers/consumer groups } \\
\text { who are interested in the } \\
\text { specific products or product } \\
\text { range }\end{array}$ \\
\hline Fish farming & Catfish & $\begin{array}{l}\text { Tilapia, Trunkfish, } \\
\text { fish, }\end{array}$ & $\begin{array}{l}\text { Consumers interested in the } \\
\text { specific products }\end{array}$ \\
\hline
\end{tabular}

\section{Dynamic Entrepreneurism}

There are inexhaustible opportunities to exploit in niche marketing for investors with entrepreneurial ability. The attributes of entrepreneurship required for constant search, identification, exploitation, improvement and expansion of such opportunities include creativity, innovativeness and calculated risk-taking (Maatman and Schrader, 2009). Entrepreneurial activities to be performed include identification of niche marketing opportunities, selection of particular opportunities for exploitation, promotion and establishment of such niches as well as the management of human and material resources for the attainment of the objectives of enterprises (Eluagu, 2008). Appropriate skills, knowledge and attitudes can enhance the ability of entrepreneurs to estimate future demands for the output of the enterprise, determine the appropriate quantities of inputs, calculate probable production costs and selling prices, among others (Eluagu, 2008).

\section{Identification of Needs and Wants of Consumers}

Niche markets can be identified by dividing a broad consumer market into attractive segments or sub-segments. One of the approaches towards achieving this includes segmentation and targetting. The other approach is the exploring of capability, core competency and competitive advantage of existing firms. Segments created out of a defined market in the process of segmentation are evaluated and profiled. Important 
Creative commons User License: CC BY-NC-ND

Abstracted by: EBSCOhost, Electronic Journals Service (EJS), Google Scholar, Directory of Open Access Journals (DOAJ), Journal Seek, Scientific Commons,

Food and Agricultural Organization (FAO), CABI and Scopus
Journal of Agricultural Extension

Vol. 21 (3) October, 2017

ISSN(e): 24086851; ISSN(Print); 1119944X

http://journal.aesonnigeria.org

http://www.ajol.info/index.php/jae

Email: editorinchief@aesonnigeria.org

statistical techniques useful in segmentation include cluster analysis, conjoint analysis, multidimensional scaling, logistic regression analysis, factor analysis and canonical analysis (Kotler, 2003). Table 2 has the basic ingredients required to illustrate the process of segmentation. It is the result of a study carried out by Anzaku et al (2013) to segment meat market in Lafia town of Nasarawa State in Nigeria, using attributes that influenced the choice of meat. Hierarchical cluster analysis using average linkage (between groups) method produced three segments which were evaluated and profiled as quality-based, demographic-based and handling-based. Segments evaluated to be viable were:i heterogeneous/homogeneous (similar or vary in needs);

ii measurable using research data;

iii substantial or broad;

iv accessible or promotable

v actionable or practical for firms to market; and

vi responsive todistinct market mix; .

Thus, meeting the evaluation criteria for the viability of segments created (www.segmentationstudyguide.com). Similarly, factors useful in developing a segment profile were considered. These factors (www.segmentationstudyguide.com) include:

i key measures such as segment size, growth and proportion of the overall market;

ii consumer behaviour with emphasis on geographic spread, demographic and psychographic description variables; and competition, dealing essentially with competitive offerings and media choices.

The quality-based and handling-based segments depicted markets where the consumers have roughly the same (homogeneous) preferences, while the demographic-based segment showed that consumers were heterogeneous (vary) in their preferences. The attributes that characterize quality-based segment included juiciness, flavour, tenderness, fresh aroma of meat and perceived nutrient content (Anzaku et al.2013). Demographic-based segment had attributes such as religion, social status, age, gender, family size and disposable income from which niche markets can be created (Anzaku et al, 2013). The handling-based segment which had professionalism and home-reared livestock as attributes indicates the potential for meat as a niche market opportunity for those producing livestock. Out of the 200 respondents who were consumers of meat in the study by Anzaku et al (2013), 33\% of them were influenced in their choice of meat by quality-based attributes, $50 \%$ by demographic-based attributes and $17 \%$ by handling-based attributes.

If any profiled segment is found attractive, it can then be selected as the target market. The attractiveness of each segment is evaluated by assessing for financial related issues, structural attractiveness, strategic direction and marketing expertise (www.segmentationstudyguinde.com) Financial-related issues involved are profit margins, and segment size and growth rate, while structural attractiveness relate to competitors and distribution channels. For strategic direction, the segment has to fit with firm's strategy and goals. Marketing expertise required are resources, capacity and branding (www.segmentationstudyguide.com). Some or all of these factors may be considered useful. 
Creative commons User License: CC BY-NC-ND

Abstracted by: EBSCOhost, Electronic Journals Service (EJS),

Google Scholar, Directory of Open Access Journals (DOAJ),

Journal Seek, Scientific Commons,

Food and Agricultural Organization (FAO), CABI and Scopus
Journal of Agricultural Extension

Vol. 21 (3) October, 2017

ISSN(e): 24086851; ISSN(Print); $1119944 X$

http://journal.aesonnigeria.org

http://www.ajol.info/index.php/jae

Email: editorinchief@aesonnigeria.org

Table 2: Segments and segment profile of the influence of attributes on the choice of meat in Lafia town

\begin{tabular}{|c|c|c|c|c|}
\hline Segment & Segment name & Attributes & $\begin{array}{l}\text { Number of } \\
\text { respondents }\end{array}$ & $\begin{array}{l}\% \text { of } \\
\text { respondents }\end{array}$ \\
\hline 1 & Quality-based & $\begin{array}{l}\text { Juiciness, flavour, tenderness, } \\
\text { fresh aroma, perceived nutrients }\end{array}$ & 66 & 33 \\
\hline 2 & $\begin{array}{l}\text { Demographic- } \\
\text { based }\end{array}$ & $\begin{array}{l}\text { Religion, social status, age, } \\
\text { gender, family size, income }\end{array}$ & 100 & 50 \\
\hline 3 & Handling-based & Professionalism, home-based & 34 & 17 \\
\hline Total & & & 200 & 100 \\
\hline
\end{tabular}

Source: Adapted from Anzaku et al. (2013)

An existing firm can also identify niche marketing opportunities by exploring its capabilities, core competencies and competitive advantage. Capability is a function of the set of skills and knowledge of the firm's employees. Core competency refers to what a firm does well, and competitive advantage is what a firm does better than its competitors. The different core competencies of a firm can be explored to identify areas flexible and responsive enough to be niche markets (Thilmany, http://valueaddedag.org). A mixed farm with special skills and resources whose core competency is livestock production may have the competitive advantage (distinctive competence) of producing organics of crop origin as a niche product. To get to the target niche market, the niche product will have to be evaluated for attractiveness as pointed out earlier.

\section{Nurturing Target Niche Market to Desired Fruition}

After selecting the target markets, suitable products are developed at suitable prices, with suitable distribution channels and effective promotional programmes. Review of performance on regular basis for an all-round success is necessary and important. In developing product offerings, consideration is given to the specific segments of the market whose consumers may want generic or differentiated products. A generic product such as maize, wheat, livestock feeds, sesame, millet or yam from different sources and similar packaging materials appears homogeneous to consumers and can be identified by the name of the product only (Broadway and Broadway, 2002). A product is differentiated if it is branded or has distinctive features such as quality, colour or form that makes it different from those of competitors. A brand is identified by a name, term, symbol, sign, design or a combination of these (Agbonifoh, Ogwo, Nnolim and Nkamnebe, 2007).

Docherty explained the different types of brands common to farm commodities. These are producer brands, varietal brands, geographical brands and certification brands. While producers distinguish between different products and their producers by using brand name, for example, Jablum Coffee, the owner of any variety uses a varietal brand name such as Pink Lady Apples to distinguish between different varieties of the product. Other brands explained are geographical brands, for example, Idaho Potatoes, and certification brands, for example, fair trade, used by public sector bodies or regional associations and certification bodies to distinguish products through their geographical origins and ethical or social standards, respectively. 
Creative commons User License: CC BY-NC-ND

Abstracted by: EBSCOhost, Electronic Journals Service (EJS),

Google Scholar, Directory of Open Access Journals (DOAJ),

Journal Seek, Scientific Commons,

Food and Agricultural Organization (FAO), CABI and Scopus
Journal of Agricultural Extension

Vol. 21 (3) October, 2017

ISSN(e): 24086851; ISSN(Print); 1119944X

http://journal.aesonnigeria.org

http://www.ajol.info/index.php/jae

Email: editorinchief@aesonnigeria.org

It is also pertinent to develop a positioning strategy. Positioning is the act of designing the firm's offering and image to occupy a distinctive place in the minds of consumers of the target market (Kotler, 2003). The goal is to locate the brand in the minds of consumers to maximize the potential benefit to the firm. A good brand positioning helps guide marketing strategy by clarifying the brand's essence, what goals it helps the consumer to achieve and how it does so in a unique way.

\section{Conclusion and Recommendations}

Niche marketing can be a means of diversifying core farm businesses. It is also useful in developing additional or new income streams for existing firms. Training tailored towards the specific needs of farmers, business people and extension workers is necessary for niche marketing to achieve its desired ends in Nigeria. The government should therefore facilitate the training of extension workers, farmers and business people in this specialized aspect of marketing for the overall good of the participants and the economy .

\section{References}

Agbonifoh, B.A, Ogwo, O.E, Nnolim, D.A. and Nkamnebe, A.D. (2007). Marketing in Nigeria. Concepts, Principles and Decisions, $2^{\text {nd }}$ Edition. Afritowers Limited, Aba, Nigeria.

Anzaku, T.A.K, Anda, S.A. and Agwale, A.O. (2013). Preferences for the types of meat consumed in Lafia Local Government Area of Nasarawa State, Nigeria. Journal of Production Agriculture and Technology (PAT), 9(1), 91 - 97.

Broadway, A.C, and Broadway, A.A. (2002). A Textbook of Agribusiness Management. Kalyani Publishers, New Delhi

Docherty, C. Branding agricultural commodities: The development case for adding value through branding. Available at http://pub.iied.org/16509IIED.html. Accessed 03/03/2017

Eluagu, L.S. (2008). The role of Agricultural Colleges in promoting entrepreneurship skills. In: Managing Resources for Effective Technological Manpower Training in Agriculture: Prospects of Entrepreneurship for Agricultural Technicians, pp. 35. Proceedings of the $14^{\text {th }}$ Agricultural Seminar, College of Agriculture, Lafia. 2-5 December

extension.psu.edu/.../farm/marketing/...what-is-niche-marketing. What is niche marketing?

http://ageco.ext.tamu.edu/file/2013/10rml-2.pdf.Nichemarketingriskmanegement Accessed 20/03/2017

http://www.agmrc.org/commodities-products/livestock/pork/niche-ethnic-pork. Accessed 12/02/2017

Kotler, P. (2003). 11 $1^{\text {th }}$ Edition. Marketing Management, $11^{\text {th }}$ Edition. Prentice-Hall of India Private Limited, New Delhi.

Maatman, A and Shrader, T. (2009). Enhancing farmers entrepreneurship: creating conditions for growth. LEISA: Magazine on Low Input and Sustainable Agriculture, 25(2), 6-8

Thilmany, D. what are niche markets. Pdf. What are niche market? What advantages do they offer? Available at http://pub.iied.org/16509lIED.html. Accessed $12 / 03 / 2017$ 
Creative commons User License: CC BY-NC-ND

Abstracted by: EBSCOhost, Electronic Journals Service (EJS),

Google Scholar, Directory of Open Access Journals (DOAJ),

Journal Seek, Scientific Commons,

Food and Agricultural Organization (FAO), CABI and Scopus
Journal of Agricultural Extension

Vol. 21 (3) October, 2017

ISSN(e): 24086851; ISSN(Print); $1119944 X$

http://journal.aesonnigeria.org

http://www.ajol.info/index.php/jae

Email: editorinchief@aesonnigeria.org

www.businessdictionary.com/definition/niche-marketing.htm. Accessed 24/02/2017 www.segmenttationstudyguide.com/...market-segmentation/a-step-by-step-guide-tosegmenting-a-market/ A step-by-step guide to segmenting a market. 